\title{
Determinants of Audit Quality in Indonesia Supreme Audit Institution: A Conceptual Study
}

\author{
Fahmi Givari Akbar, Khoirul Aswar \& Noegrahini Lastiningsih \\ Universitas Pembangunan Nasional Veteran Jakarta, Indonesia \\ aswar_law@yahoo.com
}

\begin{abstract}
This research is based on the problem of poor audit practices by the Big Four audit firms and the mid-tier audit firms in UK in 2018/2019 cycle, which is indicated as audit failure. This resulted in sanctions and fines that increased significantly from the previous year. Problems related to audit quality are also experienced by government internal auditors in Indonesia. This is due to several factors such as the quality of government internal auditor resources that are still below the lowest service standards as a public institution, lack of available apparatus and low competency, and limited budget. The purposes of this study are to determine the extent of audit quality produced by government internal auditors at the Principal Inspectorate of Indonesia's Supreme Audit Institution. Based on attribution theory, this study has several objectives, namely to determine the effect of competence, independence, and motivation on audit quality. Therefore, the contribution of this research can be the object of consideration and evaluation for Indonesia's Supreme Audit Institution auditors regarding the audit process and audit results in the public or government sector, an information for Principal Inspectorate of Indonesia's Supreme Audit Institution as an effort to maintain and improve the quality of government internal audits, and an information for the public in overseeing the audit quality of the management and responsibility of state finances.
\end{abstract}

Keywords: Audit Quality, Competence, Independence, Motivation.

\section{Introduction}

Public sector or government audit is a form of accountability for the government to the public regarding the management of state finances and as a guarantee for the implementation of good governance. The audited financial statements can be an information for the public in overseeing the audit quality of the, management and responsibility of state finances. During the 2018/2019 cycle, the Financial Reporting Council (FRC) inspection team in UK found many poor audit practices by the Big Four audit firms and the mid-tier audit firms indicated as audit failures, this resulted in sanctions and fines of $£ 42,9$ million, increased from the 2017/2018 cycle of $£ 15.5$ million (Accountancy Daily, 2019). In Indonesia, there are a number of cases involved Indonesia's Supreme Audit Institution auditors. First, the case of bribery to the Indonesia's Supreme Audit Institution auditors for Examination with Specific Purposes to change the amounts of financial findings of PT Jasa Marga in 2016, which was initially around Rp 13 billion to Rp 842.9 million. Second, Indonesia's Supreme Audit Institution auditors and Village Ministry officials including the Inspector General who are involved in bribery cases to provide an unqualified opinion on the 2016 financial statements (Tirto.id, 2019). Performance Report of Financial and Development Supervisory Agency (FDSA) 2017/2018 revealed that the quality of the government's internal auditor resources is still below the lowest service standard as a public institution with the following details: $33.6 \%$ are still at level $1,43.1 \%$ are at level 2 , and only $23.3 \%$ are at level 3.

The Indonesia's Corruption Eradication Commission stated there were three factors that made the government internal auditors ineffective, including: (1) Government Internal Oversight Apparatus's (GIOA) position in the organizational structure of the regional government is too low (the Regional GIOA is under the Regional Secretary); (2) lack of available apparatus and low competency; and (3) limited budget (KPK, 2017). The perception of audit quality is important because it can help regulators and the accounting profession in formulating policies based on empirical evidence (Al-Khaddash, Al Nawas \& Ramadan, 2013). DeFond and Zhang (2014) believes that the higher audit quality will increase assurance of higher quality financial reporting. Audit quality can limit managerial opportunistic attitudes and can detect the possibility of audit failure by the auditor (de las Heras, Canibano \& Moreira, 2012). There are several studies that show factors that can influence audit quality in the private or public sector. Patrick, Vitalis and Mdoom (2017) and Ismail, Merejok, Dangi and Saad (2019) found empirical evidence that independence has a positive effect on audit quality. Meanwhile, research by Kertarajasa, Marwa and Wahyudi (2019) stated that auditor independence has no effect on audit quality. Audit quality is also influenced by competency factors. Research results by 
Zahmatkesh and Rezazadeh (2017), Ismail et al. (2019) and Kertarajasa et al. (2019) concluded that competence has a positive effect on audit quality. Meanwhile, different results were shown in the study Hikmayah and Aswar (2019) proved that, competence has no effect on audit quality.

Then, motivation becomes a factor that must be considered as a determinant of audit quality. In research Idawati (2015) and Asmara (2016) found a positive relationship between motivation and audit quality. However, research conducted by Furiady and Kurnia (2015) and Zahmatkesh and Rezazadeh (2017) found no relationship between motivation and audit quality. This paper focuses on a conceptual model which will form the basis of un-coming studies in exploring audit quality with a focus on government internal auditor at the Principal Inspectorate of Indonesia's Supreme Audit Institution. Public sector or government audit is a form of accountability for the government to the public regarding. The purpose of this study is to determine the relationship of competence, independence, and motivation on audit quality.

\section{Literature Review and Hypothesis Development}

Theory: Attribution theory provides an explanation of how to determine the cause or motive for a person's behavior. This theory is directed to develop explanations of ways of valuing people differently, depending on what meaning will be attributed to a behavior. This theory also reveals that a person's behavior is determined by a combination of internal forces, namely factors from within a person, such as personality, self-perception, ability, or motivation, and external forces, namely factors that come from outside, such as pressure, environmental, or social.

Hypothesis Development: The development of hypothesis in this study is based on factors that are expected having an influence on the audit quality; therefore it can be formulated as follows:

Competence: Ability and expertise are considered related to audit quality (Mansouri, Pirayesh \& Salehi, 2009; Chen, Hsu, Huang \& Yang, 2013). The auditor's expertise can gradually develop through training and practical experience from the audit process. Auditors must have special knowledge to enable them to better detect misstatements of financial statements (Hakim \& Omri, 2010). Research by Halim et al. (2014), Zahmatkesh and Rezazadeh (2017), Kertarajasa et al. (2019), Ismail et al. (2019) and Aswar et al. (2020) found that competence has a significant effect on audit quality. Every auditor must comply with certain requirements to become a professional auditor. Based on the explanation above, the hypothesis is formulated as follows:

H1: Competence has a significant effect on audit quality.

Independence: The possibility of the auditor not reporting material misstatement depends on the auditor's independence. If auditors cannot maintain their independence, this will certainly have an impact on reducing audit quality (Deis \& Giroux, 1992). Mansouri et al. (2009) argued that if the auditor is less competent, the auditor tends to depend on client management; this can disrupt the independence of the client. Research results by Zahmatkesh and Rezazadeh (2017), Patrick et al. (2017), and Ismail et al. (2019) proved that independence has a significant effect on audit quality. Therefore, the higher independence of auditors will improve the audit quality produced. Based on the explanation above, the hypothesis is formulated as follows: H2: Independence has a significant effect on audit quality.

Motivation: Audit quality will be high if the wants and needs of auditors can be realized. Therefore, great motivation is needed so that the task can be completed properly (Zahmatkesh \& Rezazadeh, 2017). Mathis and Jackson (2004) revealed that the main factor influencing individual performance was the level of effort expended or motivation. Research results by Idawati (2015) and Asmara (2016) concluded that motivation has a significant effect on audit quality. Based on the explanation above, the hypothesis is formulated as follows:

H3: Motivation has a significant effect on audit quality. 


\section{Proposed Method}

This study recommends an appropriate method to test the proposed conceptual framework for empirical studies, where data can be collected from respondents. The target population in this study is all apparatus of Principal Inspectorate of Indonesia's Supreme Audit Institution. Determination of this population is based on the reason that many problems occur related to the audit quality of the government internal auditors. In addition, the audit quality of Indonesia's Supreme Audit Institution began to be questioned as corruption cases arose involving Indonesia's Supreme Audit Institution auditors and local government officials whose financial statements received unqualified opinion from Indonesia's Supreme Audit Institution. There are 67 officials and staff in the Principal Inspectorate of Indonesia's Supreme Audit Institution, which are divided into two parts, namely the Inspectorate of Obtaining Quality Inspection (IOQI) and the Inspectorate of Internal Inspection and Institutional Quality (IIIQ).

Table 1: List of Structural Position of Principal Inspectorate of Indonesia's Supreme Audit Institution

\begin{tabular}{lll}
\hline Structural Position & Inspectorate PKMP & Inspectorate PIMK \\
\hline Inspector & 1 & 1 \\
Head of Department & 3 & 2 \\
Head of Sub-Department & 7 & 5 \\
Staff & 26 & 22 \\
Total Number of Auditors & $\mathbf{3 7}$ & $\mathbf{3 0}$ \\
\hline
\end{tabular}

\section{Conclusion}

The conceptual paper of this study aims to examine the factors that influence audit quality on government internal audits, especially in the Principal Inspectorate of Indonesia's Supreme Audit Institution. This is important because the government internal auditors must be able to ensure public accountability carried out by the Central / Regional Government and State-Owned Enterprises (BUMN) / Regional-Owned Enterprises (BUMD). Public sector or government audit is a form of accountability for the government to the public regarding the management of state finances and as a guarantee for the implementation of good governance. Factors that influence audit quality are measured by 42 statements. The results of this study are expected to contribute significantly for Indonesia's Supreme Audit Institution auditors as an object of consideration and evaluation regarding the audit process and audit results in the public or government sector, being an information for Principal Inspectorate of Indonesia's Supreme Audit Institution in an effort to maintain and improve the quality of government internal audits, and a consideration for the government in the formulation of policies and regulations relating to audits, and also being an information for the public in overseeing the audit quality of the management and responsibility of state finances. Overall, the outcomes of the papers in this study must also provide valuable insights for Supreme Audit Institution auditors, and supporting the call for ongoing research in this exciting and unexplored field.

\section{References}

Accountancy Daily. (2019). Regulator hands out record $£ 43$ million fines for bad audit. From: https://www.accountancydaily.co/regulator-hands-out-record-ps43m-fines-bad-audit.

Al-Khaddash, H., Al Nawas, R. \& Ramadan, A. (2013). Factors affecting the quality of auditing: The case of Jordanian Commercial Banks. International Journal of Business and Social Science, 4(11), 206-222.

Asmara, R. (2016). Effect of competence and motivation of auditors of the quality of audit: Survey on the external auditor registered public accounting firm in Jakarta in Indonesia. European Journal of Accounting, Auditing and Finance Research, 4(1), 43-76.

Aswar, K., Ermawati, E., Wiguna, M. \& hariyani, E. (2020). A conceptual framework on the audit quality in the government internal audit in Indonesia. Information Management and Business Review, 12(1), 22-26.

Chen, Y., Hsu, Y., Huang, M. \& Yang, P. (2013). Quality, size and performance of audit firms. The International Journal of Business and Finance Research, 7(5), 89-105.

DeFond, M. \& Zhang, J. (2014). A review of archival auditing research. Journal of Accounting \& Economics, 58, 275-326. 
Deis, D. \& Giroux, G. (1992). Determinants of audit quality in the public sector. The Accounting Review, 67(3), 462-479.

de las Heras, E., Cañibano, L. \& Moreira, J. A. (2012). The impact of the spanish financial act (44|2002) on audit quality. Revista Española de Financiación y Contabilidad, 41(156), 521-546.

Furiady, 0. \& Kurnia, R. (2015). The effect of work experience, competence, motivation, accountability and objectivity towards audit quality. Procedia - Social and Behavioral Sciences, 211, 328-335.

Hakim, F. \& Omri, A. (2010). Quality of the external auditor, information asymmetry, and bid-ask spread. International Journal of Accounting and Information Management, 18(1), 5-18.

Halim, A., Sutrisno, T., Rosidi. \& Achsin, M. (2014). Effect of competence and auditor independence on audit quality with audit time budget and professional commitment as a moderation variable. International Journal of Business and Management Invention, 3(6), 64-74.

Hikmayah, N. \& Aswar, K. (2019). The impact of factors on the audit quality in Indonesia: The moderating effect of professional commitments. International Journal of Academic Research in Accounting, Finance and Management Sciences, 9(4), 285-293.

Idawati, W. (2015). Effect of audit rotation, audit fee and auditor competence to motivation auditor and implications on audit quality (Case study of registered public accountant firms at Bank Indonesia). Journal of Economics and Sustainable Development, 6(6), 51-59.

Ismail, A. H., Merejok, N. B. M., Dangi1, M. R. M. \& Saad, S. (2019). Does audit quality matters in Malaysian public sector auditing?. International Journal of Financial Research, 10(3).

Kertarajasa, A. Y., Marwa, T. \& Wahyudi, T. (2019). The effect of competence, experience, independence, due professional care, and auditor integrity on audit quality with auditor ethics as moderating variable. Journal of Accounting, Finance and Auditing Studies, 5(1), 80-99.

Mansouri, A., Pirayesh, R. \& Salehi, M. (2009). Audit competence and audit quality: Case in emerging economy. International Journal of Business and Management, 4(2), 17-25.

Mathis, R. L. \& Jackson, J. H. (2004). Human Resource Management. $10^{\text {th }}$ Edition. Ohio, South-Western.

Patrick, Z., Vitalis, K. \& Mdoom, I. (2017). Effect of auditor independence on audit quality: A review of literature. International Journal of Business and Management Invention, 6(3), 51-59.

Tirto.id. (2019). Kasus Rizal Djalil dan korupsi-korupsi lain di BPK RI. From: https://tirto.id/kasus-rizaldjalil-dan-korupsi-korupsi-lain-di-bpk-ri-eiQw (accessed: March 03, 2020)

Zahmatkesh, S. \& Rezazadeh, J. (2017). The effect of auditor features on audit quality. Tékhne - Review of Applied Management Studies, 15(2), 1-9. 